\title{
FK506 and Lactobacillus Acidophilus Ameliorate Acute Graft-Versus-Host Disease by Modulating the T Helper 17/Regulatory T-Cell Balance
}

\section{Jin-ah Baek}

The Catholic University of Korea

Min-Jung Park

The Catholic University of Korea

Se-Young Kim

The Catholic University of Korea

JooYeon Jhun

The Catholic University of Korea

\section{Jin Seok Woo}

The Catholic University of Korea

Jeong Won Choi

The Catholic University of Korea

\section{Hyun Sik $\mathrm{Na}$}

The Catholic University of Korea

\section{Soon Kyu Lee}

The Catholic University of Korea

Jong Young Choi

The Catholic University of Korea

Mi-La Cho ( $\square$ iammila@catholic.ac.kr)

Catholic University of Korea https://orcid.org/0000-0001-5715-3989

\section{Research Article}

Keywords: L. acidophilus, FK506, Th17 cell, regulatory T cell, allogeneic response, GvHD, liver transplantation

Posted Date: December 1st, 2021

DOI: https://doi.org/10.21203/rs.3.rs-1084019/v1

License: (c) (1) This work is licensed under a Creative Commons Attribution 4.0 International License. Read Full License 
Version of Record: A version of this preprint was published at Journal of Translational Medicine on February 25th, 2022. See the published version at https://doi.org/10.1186/s12967-022-03303-z. 


\section{Abstract \\ Background}

Graft-versus-host disease (GvHD) is critical complication after allogeneic hematopoietic stem cell transplantation (HSCT). The immunosuppressants given to patients undergoing allogeneic HSCT disturb the microbiome and the host immune system, potentially leading to dysbiosis and inflammation, and may affect immune function and bone marrow transplantation. The intestinal microbiome is a target for the development of novel therapies for GvHD. Lactobacillus species are in widely used supplements to induce production of antimicrobial and anti-inflammatory factors.

\section{Methods}

We determined the effect of the combination of Lactobacillus acidophilus and FK506 on GvHD following major histocompatibility complex-mismatched bone marrow transplantation.

\section{Results}

The combination treatment suppressed IFN- $\gamma$ and IL-17-producing T cell differentiation, but increased Foxp $3^{+}$Treg differentiation and IL-10 production. Also, the combination treatment and combination treated-induced Treg cells modulated the proliferation of murine alloreactive T cells in vitro. Additionally, the combination treatment upregulated Treg-related genes-Nt5e, Foxp3, Ikzf2, Nrp1 and Itgb8-in murine $\mathrm{CD} 4^{+}-\mathrm{T}$ cells. The combination treatment also alleviated GvHD clinically and histopathologically by controlling the effector $\mathrm{T}$ cell and Treg balance in vivo. Moreover, the combination treatment decreased Th17 differentiation significantly and significantly upregulated Foxp3 and IL-10 expression in peripheral blood mononuclear cells from healthy controls and liver transplantation (LT) patients.

\section{Conclusions}

Therefore, the combination of $L$. acidophilus and FK506 is effective and safe for patients undergoing allogeneic hematopoietic stem cell transplantation.

\section{Background}

Allogeneic hematopoietic stem cell transplantation (allo-HSCT) is a remedial treatment modality for most hematologic malignancies. Its main complication, graft-versus-host disease (GvHD) affects the skin, liver, and gastrointestinal tract. GvHD is mediated by donor T cells in the graft and leads to a high rate of transplantation-related mortality [1, 2]. 
Tacrolimus (also known as FK506), a calcineurin inhibitor, is an anti-T-cell agent that is among the most widely used immunosuppressants [3]. FK506 inhibits calcineurin phosphatase and calcium-dependent events by binding to FK506 binding protein 12 (FKBP12), thereby preventing the dephosphorylation of nuclear factor of activated T-cells (NFAT) family members responsible for transcription of the T-cellactivating cytokines interleukin-2 and -4 [4-7]. However, use of FK506 is associated with nephrotoxicity and can lead to dysbiosis [8-10].

The altered intestinal microbiota of patients with GvHD is correlated with GvHD severity and pathogenesis [11-13]. Intestinal bacteria of the order Clostridiales are important mediators of intestinal homeostasis [14-16] and the loss of intestinal bacteria of the genus Blautia, a member of the order Clostridiales, is associated with an increased mortality rate from GvHD [17]. Therefore, controlling the intestinal microbiota composition may be useful for preventing and treating GvHD [18].

Supplementation of probiotics may benefit gut-related immunity [19]. In mice, Lactobacillus rhamnosus reduced histologic inflammation and decreased the mortality rate post-transplantation [20]. Lactobacillus species exert an anti-inflammatory effect in vitro, and elimination of Lactobacillus species prior to alloHSCT correlates with increased GvHD severity [21, 22].

We hypothesized that treatment with the combination of L. acidophilus and FK506 would ameliorate inflammation and GvHD. We evaluated the effect of L. acidophilus plus FK506 on GvHD in vitro and in vivo.

\section{Methods}

\section{Mice}

C57BL/6 $\left(B 6, H-2 k^{b}\right)$ and BALB/c $\left(B / c, H-2 k^{d}\right)$ mice at 8-10 weeks of age were purchased from OrientBio (Sungnam, Korea). The Institutional Animal Care and Use Committee (IACUC) and Department of Laboratory Animal of the Catholic University of Korea (Songeui Campus) accredited the Korea Excellence Animal laboratory Facility from Korea Food and Drug Administration in 2017 and acquired full accreditation by AAALAC International in 2018. Animal procedures were performed in accordance with the Laboratory Animals Welfare Act, the Guide for the Care and Use of Laboratory Animals, and the Guidelines and Policies for Rodent Experiments of the IACUC of the School of Medicine of The Catholic University of Korea (Approval number : CUMC-2020-0177-01).

\section{Patients}

For this study, Liver transplantation (LT) patients were prospectively enrolled from a single LT clinic at Seoul St. Mary's Hospital. The inclusion criteria were: more than 18 years old, liver transplanted more than 3 years ago; with 0-1 HLA-A, -B, and -DR mild mismatched; a high level of liver function with no history of rejection. Eight patients are being treated with CNIs including cyclosporine and tacrolimus. This 
study was approved by the Institutional Review Board of the Catholic University of Korea (KC19OESI0617).

\section{Murine splenocyte and human peripheral blood mononuclear cell culture and stimulation in vitro}

Spleens from B6 mice were homogenized and red blood cells were lysed with ACK lysis buffer $(0.15 \mathrm{M}$ $\mathrm{NH}_{4} \mathrm{Cl}, 10 \mathrm{mM} \mathrm{KHCO}_{3}$, and $0.1 \mathrm{mM}$ ethylenediaminetetraacetic acid; $\mathrm{pH}$ 7.2-7.4). Splenocytes were filtered through a cell strainer, centrifuged at $1300 \mathrm{rpm}$ at $4^{\circ} \mathrm{C}$ for $5 \mathrm{~min}$, and resuspended in Roswell Park Memorial Institute (RPMI) 1640 medium supplemented with 5\% [v/v] heat-inactivated fetal bovine serum (FBS). Human peripheral blood mononuclear cells (PBMCs) were isolated from human blood samples. Human blood samples by adding phosphate-buffered saline (PBS) was placed onto a layer of $10 \mathrm{~mL}$ Ficoll Plaque Plus (GE Healthcare Life Sciences, Marlborough, MA, USA) and centrifuged at $2000 \mathrm{rpm}$ at $20^{\circ} \mathrm{C}$ for 30 min. After centrifugation, PBMCs were washed and maintained in RPMI 1640 medium containing 10\% FBS. A single suspension was prepared, and $1 \times 10^{6}$ cells/well in 24-well flat bottom plates were cultured in the presence of plate-bound $0.5 \mu \mathrm{g} / \mathrm{mL}$ anti-CD3. Next, the cells were treated with L. acidophilus ( $100 \mathrm{ug} / \mathrm{mL}$ ) and FK506 (0.3 nM for splenocytes; $1.0 \mathrm{nM}$ for PBMCs) for 3 days. $L$. acidophilus was made inactive by heating at $80^{\circ} \mathrm{C}, 30 \mathrm{~min}$.

\section{Murine T-cell isolation and conditioning of alloreactive T-cell responses}

To purify mouse splenic CD4 ${ }^{+}-\mathrm{T}$ cells and antigen-presenting cells (APCs), splenocytes were incubated with CD4-coated magnetic beads and isolated by magnetic-activated cell sorting (Miltenyi Biotec, Bergisch Gladbach, Germany). Splenic CD $4^{+}-T$ cells from B6 (or B/c) mice were used as stimulator cells in the context of allorecognition. APCs from B/c (or B6) mice were used as the responder cells. Aliquots of $2^{\prime} 10^{5} \mathrm{CD} 4^{+}-\mathrm{T}$ cells (responders) were cultured with $2^{\prime} 10^{5}$ irradiated (5,000 cGy) stimulators in 96 well plates containing $200 \mathrm{~mL} /$ well of complete medium, followed by treatment with $100 \mathrm{ug} / \mathrm{mL}$ L. acidophilus and/or $0.3 \mathrm{nM} \mathrm{FK506} \mathrm{(for} \mathrm{splenocytes)} \mathrm{at} 37^{\circ} \mathrm{C}$ in a humidified $5 \%(\mathrm{v} / \mathrm{v}) \mathrm{CO}_{2} /$ air atmosphere for 4 days. The cells were pulsed with $1 \mathrm{mCi}$ of tritiated thymidine $(3[\mathrm{H}]-\mathrm{TdR})$ (NEN Life Science Products, Boston, MA, USA) $18 \mathrm{~h}$ before harvesting using an automated harvester (PHD Cell Harvester; Cambridge Technology, Cambridge, MA, USA), and enumerated using a b-counter (Packard TopCount NXT). Data are expressed as mean cpm values of triplicate samples \pm SEM.

\section{In vitro co-culture systems}

To determine the blocking ability of alloreactive T-cell responses by L. acidophilus and/or FK506-induced Treg cells, we sorted the induced Treg cells and co-cultured in alloreactive condition. Anti-CD3-stimulated CD4 ${ }^{+}-T$ cells were cultured with $L$. acidophilus, FK506 and combination of L. acidophilus and FK506. Three days later, cells of each condition were immunostained with anti-CD4 and anti-CD25 (eBioscience) and the induced Treg cells were sorted using a FACS Aria Fusion (BD Siosciences). Responder cells ( $2 \times$ $\left.10^{5}\right)$ and irradiated APCs $\left(2 \times 10^{5}\right)$ were co-cultured with each induced Treg cells $\left(5 \times 10^{3}\right.$; each induced Treg to responder cells ratio is 1:40) in 96-well plates for 4 days, pulsed with $1 \mu \mathrm{Ci}$ tritiated thymidine at 
$18 \mathrm{~h}$ before the end of the experiment, and counted using an automated harvester, and enumerated using a b-counter (Packard TopCount NXT). Data are expressed as mean cpm values of triplicate samples \pm SEM.

\section{Mouse bone marrow transplantation and Scoring}

To induce GvHD, splenocytes $\left(5 \times 10^{6}\right)$ and bone marrow cells $\left(5 \times 10^{6}\right)$ were isolated from donor $(B 6)$ mice and transplanted into recipient $(\mathrm{B} / \mathrm{c})$ mice by intravenous injection after $690 \mathrm{cGy}$ irradiation. After induction of GvHD, recipient mice were orally administered $L$. acidophilus $\left(1.6 \times 10^{10} \mathrm{CFU} / \mathrm{kg}\right)$ and/or FK506 (5 mg/kg) daily. Control GvHD mice received vehicle (saline) in the same manner. The experiments were performed in at least triplicate, with five mice per group. Survival after bone marrow transplantation (BMT) was monitored daily and GvHD severity was assessed twice weekly using a scoring system based on summing changes in weight loss, posture, activity, fur texture, and skin integrity. Clinical GvHD scores were assessed using a previously described scoring system [23].

\section{Flow cytometry}

Murine splenic lymphocytes and PBMCs and human PBMCs were immunostained with fluorescently conjugated antibodies against CD4, CD8, CD25, IL-17, IFN-g, Foxp3, and Fixable-dye (BD Biosciences, San Diego, CA, USA). Prior to intracellular staining, cells were stimulated for $4 \mathrm{~h}$ with phorbol myristate acetate $(25 \mathrm{ng} / \mathrm{mL})$ and ionomycin $(250 \mathrm{ng} / \mathrm{mL})$ (Sigma-Aldrich, St. Louis, MO, USA) and treated with Golgistop (BD Biosciences). Intracellular staining was performed using a Cytofix/Cytoperm Plus Fixation/Permeabilization Kit and Golgistop Kit (BD Biosciences). The transcription factor Foxp3 was stained using a Foxp3/Transcription Factor Staining Kit (eBioscience) following the manufacturer's protocol. Flow cytometry was performed using a cytoFLEX Flow Cytometer (Beckman Coulter, Brea, CA, USA) and data were analyzed in FlowJo software (Tree Star).

\section{Enzyme-linked immunosorbent assays}

The concentrations of IFN-g, IL-17, and IL-10 in culture supernatants of splenocytes and human PBMCs stimulated with anti-CD3 were measured by sandwich enzyme-linked immunosorbent assay (ELISA) (Duoset; R\&D Systems, Lille, France).

\section{RNA sequencing}

$\mathrm{CD} 4^{+}-\mathrm{T}$ cells were isolated from B6 mice and subjected to T-cell activation conditions with or without L. acidophilus and FK506. Next-generation RNA-sequencing (RNA-seq) was conducted to quantify mRNAs and performed using a Novaseq 6000 (Illumina). Expression data were preprocessed using the range migration algorithm followed by quantile normalization. The RNA-seq data have been submitted in NCBI's Gene Expression Omnibus (GEO) and is accessible through GEO Series accession number GSE174214.

\section{Histological and immunohistochemical analyses}


Mice were euthanized on day 42 after BMT and the organs were harvested, cryoembedded, and sectioned. Tissue specimens were fixed in $10 \%$ formalin buffer and embedded in paraffin. Sections (6 $\mathrm{mm}$ thick) were stained with hematoxylin and eosin and analyzed using a histologic scoring system. For immunohistochemical staining, sections were stained with primary antibodies against IFN-g, IL-17, and IL-10 overnight at $4^{\circ} \mathrm{C}$, followed by a biotinylated secondary antibody and streptavidin-peroxidase mixture for $1 \mathrm{~h}$ (Thermo Fisher, San Diego, CA, USA). Color was developed by adding 3,3-diaminobenzidine (Dako, Carpinteria, CA, USA). A histopathology score was graded using the scoring system described by Kim et al. and Fukui et al $[23,24]$.

\section{Real-time polymerase chain reaction}

Total RNA was extracted using TRI reagent (Molecular Research Center, Inc., Cincinnati, OH, USA) according to the manufacturer's instructions. Complementary DNA was synthesized using the FirstStrand cDNA Synthesis Kit (Dyne Bio). A LightCycler 2.0 instrument (software version 4.0; Roche Diagnostics) was used for PCR amplification with The SensiFAST ${ }^{\mathrm{TM}}$ SYBR Hi-ROX Kit (Bioline) following the manufacturer's instructions. The following primers were used to amplify human genes: Foxp3, 5'-CAC TGC CCC TAG TCA TGG T-3' (sense) and 5'-GGA GGA GTG CCT GTA AGT GG-3' (antisense); and IL-10, 5'-CCA AGC CTT GTC TGA GAT GA-3' (sense) and 5'-TGA GGG TCT TCA GGT TCT CC-3' (antisense). Transcript levels were normalized to that of $\beta$-actin.

\section{Statistical analysis}

We performed one-way analysis of variance (ANOVA) with Bonferroni's post hoc test for multiple comparisons at a significance level of $p<0.05$ using Prism ver. 5.01 software (GraphPad Software Inc., San Diego, CA, USA). Data are presented as means \pm SEM.

\section{Results}

\section{Combination treatment modulates murine T-cell proliferation in vitro}

First, we investigated the effect of the combination treatment on murine IFN-g-producing T cell, IL-17producing T cell, and Treg cell differentiation in vitro. Splenocytes from normal B6 mice were cultured in the presence of an anti-CD3 antibody plus $100 \mathrm{ug} / \mathrm{mL}$ L. acidophilus and/or $0.3 \mathrm{nM} \mathrm{FK506} \mathrm{for} 72 \mathrm{~h}$. The combination treatment significantly decreased Th1 and Th17 cell proliferation, and significantly increased the proportion of Treg cells, compared to vehicle and either single treatment (Fig. 1a). The concentrations of IFN-g and IL-17 were decreased and that of IL-10 was significantly increased in combination-treated compared with vehicle-treated cells (Fig. 1b). Also, the combination treatment were significantly decreased CD $8^{+}$type 1 cytotoxic T cell (Tc1) and IL-17-producing CD $8^{+}$(Tc17) cell proliferation, and a single treatment with $L$. acidophilus was more effective than FK506 single on Tc 1 cells (Fig. 1c). To assess effects on the alloreactive T-cell response, we examined in vitro alloreactive Tcell proliferation in a mixed lymphocyte reaction. The combination treatment significantly suppressed alloreactive T-cell proliferation compared to allo and either single treatment (Fig. 1d). To confirm the 
effect of combination treatment, we sorted the Treg cells that induced by combination with $L$. acidophilus and FK506 and co-cultured in alloreactive condition. These induced Treg cells significantly suppressed alloreactive T-cell proliferation (Fig. 1e). Therefore, the combination treatment exerted an immunoregulatory effect on murine $T$ cells in vitro.

\section{Effect of the combination treatment on gene expression in CD4 ${ }^{+}-\mathrm{T}$ cells}

We next analyzed by RNA-seq the gene expression profiles of CD4 ${ }^{+}-\mathrm{T}$ cells treated with $\mathrm{L}$. acidophilus and/or FK506 in the presence of an anti-CD3 antibody (Fig. 2a). When identified by absent/present classification and using an at least two-fold difference in expression as the cut-off, 6507 genes were differentially expressed in anti-CD3-treated $\mathrm{CD} 4^{+}-\mathrm{T}$ cells versus combination-treated CD $4^{+}-\mathrm{T}$ cells (Fig. 2b). Among genes in the Th1 pathway, Tbx21 and Lgals 7 were downregulated; among those in the Th17 pathway, II13, Mapk13, II21, S/c26a10, and Gzma were downregulated by the combination treatment compared with L. acidophilus or FK506 alone. Moreover, Treg-related genes such as Nt5e, Foxp3, Ikzf2, $\mathrm{Nrp} 1$, and $\operatorname{ltg} 88$ were upregulated in combination-treated CD4 ${ }^{+}-\mathrm{T}$ cells. Regarding Th17 differentiationrelated pathway genes linked to cellular growth and proliferation, Eif4ebp 1 and Lpin3 (mTOR pathway) and Osmr, $\|13\| 17 d,, \| 21$, and Lif (JAK-STAT pathway) were downregulated by the combination treatment (Fig. 2C). Taken together, these data suggest that combination-treated CD $4^{+}-\mathrm{T}$ cells have an immunoregulatory function through the expression of Treg-related genes.

\section{Combination therapy reduced the severity of GvHD}

To verify the effect of the combination treatment, bone marrow and splenocytes from a B6 donor were transplanted into a B/c recipient. The combination treatment improved the clinical symptoms of GvHDweight loss, posture, activity, fur texture and skin integrity-compared with vehicle. The score of FK506 alone was similar to that of the combination, but the latter resulted in increased survival duration (Fig. 3a). Four weeks after BMT, we analyzed IFN-g- and IL-17-producing CD4+-T cells in mouse PBMCs by flow cytometry. The populations of Th1 and Th17 cells were decreased by the combination treatment compared with vehicle or either single treatment (Fig. 3b). Next, we performed a histopathologic analysis of skin, liver, and large intestine tissues to determine the effect of the combination treatment on inflammatory cell infiltration. In the mouse model of GvHD, vehicle group has increased collagen density in skin, lymphocyte aggregates in portal tracts with destruction of bile ducts in liver tissue, and infiltration of lymphocyte and crypt loss of intestine, compared to syngenic [23, 24]. To determine the protective combination effects of L. acidophilus and/or FK506 on the development of GVHD, we evaluated tissue pathology in skin, liver and large intestine. As shown in Fig. 3c, moderate to severe GvHD was noted in those organs of vehicle group. Combination treatment group significantly improved pathologic severity scores in the skin, liver, and large intestine. Therefore, the combination treatment attenuated GvHD in vivo.

\section{Combination treatment modulates cytokine secretion}


Next, we evaluated the expression levels of pro- and anti-inflammatory cytokines by immunohistochemistry in murine skin and liver tissues after BMT. The levels of proinflammatory cytokines, such as IFN-g and IL-17, were significantly decreased by the combination treatment versus vehicle in skin and liver tissue. Also, the IFN-g level in skin tissue was significantly decreased by the combination treatment compared with either single treatment (Fig. 4a, b). The concentration of IL-10, an anti-inflammatory cytokine, was significantly increased by the combination treatment compared with vehicle and either single treatment (Fig. 4c). Therefore, the combination of L. acidophilus and FK506 after BMT regulates T-cell infiltration of target tissues.

\section{Effect of the combination treatment on human PBMCs in vitro}

To investigate the regulatory effect of the combination treatment on human Th1 and Th17 cell differentiation, PBMCs from healthy controls $(n=6)$ and LT patients $(n=8)$ were cultured under anti-CD3 conditions with L. acidophilus and/or FK506 for $72 \mathrm{~h}$ in vitro. Flow cytometry showed that the combination treatment significantly decreased Th1 and Th17 cell proliferation (Figs. 5a and 6a) and increased Treg cells compared with FK506 and vehicle (Figs. 5c, and 6b). The concentrations of IFN$\mathrm{g}$ and IL-17 were decreased and that of IL-10 was significantly increased by the combination treatment compared with FK506 or vehicle (Fig. 5b). Also, the transcript levels of Foxp3 and IL-10 were significantly increased by the combination treatment in PBMCs from healthy controls and LT patients (Figs. 5d, 6b). Therefore, the combination treatment suppressed human Th17-cell and promoted human Treg-cell proliferation in vitro.

\section{Discussion}

Tacrolimus (FK506) is an immunosuppressant used to prevent allograft and treat autoimmune disease [25-28]. However, immunosuppressive agents increase susceptibility to infections and alter the gut microbiota composition, the latter is associated with the severity and pathogenesis of GvHD [10-13,29]. For this reason, maintaining the optimal concentration of tacrolimus is important for patient survival; however, determining the optimum concentration is hampered by interindividual variation in tacrolimus efficacy [30-32]. We hypothesized that $L$. acidophilus could ameliorate the side effects of FK506, and thus mitigate GvHD following MHC-mismatched bone marrow transplantation.

Probiotics supplementation is widely used in clinical practice, and promotes re-growth of beneficial species, ameliorating diseases such as IBD, colitis, RA, and osteoporosis [33-37]. IFN-y-producing T cell such as Th1 and Tc1, IL-17-producing T cell such as Th17 and Tc17 are crucial mediators of GvHD [38$43]$ and GvHD is associated with a reversed proportion of Tregs [44, 45]. Lactobacillus species, probiotics widely used as health supplements, are commensal bacteria that reduce inflammation by stimulating lymphocytes via IL-10 $[46,47]$. In this study, the combination treatment significantly decreased the population of Th1, Tc1, Th17 and Tc17 cells (Figs. 1a, 1c, 5a, 5c, 6a and 6b) as well as the IFN-Y and IL-17 concentrations, but significantly increased the population of Treg cells and the IL-10 concentration, compared with FK506 alone (Figs. 1a, 1b, 5b, 5c and 6b) in murine and human. Moreover, the alloreactive 
T-cell response was decreased significantly by the combination treatment (Fig. 1d). However, the transcript levels of Foxp3 and IL-10 in human PBMCs were significantly increased by the combination treatment (Figs. $5 \mathrm{~d}, 6 \mathrm{~b}$ ). Further study is required to confirm that combination treatment of $L$. acidophilus with FK506 can modulate Tc1 and Tc17 cell in vivo and human in vitro.

Dysbiosis of the gut microbiota influences immune tolerance and triggers autoimmune and inflammatory diseases by causing an imbalance of $T$ cell subsets $[48,49]$. L. acidophilus has immunomodulatory properties such as modulating Th17 and Treg cell populations. L. acidophilus induced production of Treg cells and IL-10, but suppressed that of IL-17, in splenocytes [35]. In addition, the immunoregulatory function of Tregs is used in the therapeutic strategies for autoimmune disease such as SLE, RA and GvHD because mechanisms of Treg cells that have been modulation of cell proliferation [50-53]. In this study, combination treated-induced Treg suppressed the T cell proliferation (Fig. 1e) and the combination treatment reduced the effector T-cell population by modulating Th17, mTOR, and JAK-STAT signaling, and upregulating Treg-related genes, compared to L. acidophilus and FK506 alone (Fig. 2). In particular, Treg-related genes, Nt5e, Foxp3, Ikzf2, Nrp1 and Itgb8, are up-regulated by combination treatment of $L$. acidophilus and FK506. Nt5e, also known as CD73, is known to have immunosuppressive potential through restricting inflammatory immune responses [54,55]. Foxp3 is essential for the maintenance of Treg and Nrp 1 is required to maintain Treg stability and function [56-58]. Deficiency of $l k z f 2$ (as known as Helios) and Itgb8 cannot control the expansion of pathogenic T cells during active inflammation [59, 60]. It could be suggested that the combination showed a greater effect than single treatment of FK506 because of the Treg-related genes. Therefore, $L$. acidophilus improved the immunological imbalance caused by FK506 by decreasing and increasing the Th17 and Treg cell populations in vitro.

L. acidophilus reduced the serum IL-6 and IL-17 levels and downregulated IL-17A expression, but upregulated CD25, Foxp3, and TGF- $\beta$ expression in a murine model of allergy [61]. Also, L. acidophilus leads to the Treg-Th17 cell balance by inhibiting Th17 cells and promoting Treg cells in ovariectomized mice [62]. We used $L$. acidophilus because of its immunoregulatory activity, as confirmed in this study by its in vivo and in vitro immunoregulatory effects on Th17 and Treg cells in a GvHD model. Indeed, the combination treatment improved the clinical scores of mice with GvHD. Moreover, the combination therapy reduces the Th1 and Th17 cell populations compared with vehicle after 4 weeks in vivo (Fig. 3b). In GvHD target tissues, such as skin and liver, the levels of proinflammatory cytokines were significantly decreased and that of an anti-inflammatory cytokine was significantly increased by the combination treatment (Fig. 4). Therefore, the combination treatment suppressed inflammation and pathogenic cell activity.

Taken together, the results show that treatment with L. acidophilus or FK506 exerted similar effects, which were of lesser magnitude than those of the combination treatment. In other words, L. acidophilus served as a supplement to low-dose FK506 in a GvHD model and showed synergistic effects in this study.

\section{Conclusions}


In conclusion, improvement of immune imbalance by probiotics has therapeutic potential for GvHD. Addition of L. acidophilus to FK506 reduced inflammation and the severity of GvHD compared to FK506 alone in vivo and in vitro. We propose that the combination treatment of L. acidophilus with FK506 could prevent GvHD progression through effector T cell and Treg cell modulation, also L. acidophilus could reduce the side effects and maximize the therapeutic efficacy of FK506 in allo-HSCT patients.

\section{Declarations}

\section{Acknowledgements}

None.

\section{Author contribution}

J.A.B., M.J.P. and M.L.C. designed the experiments. J.A.B., M.J.P. and S.Y.K. performed the experiments. J.A.B., M.J.P., S.Y.K., J.Y.J., J.S.W., J.W.C., H.S.N., and M.L.C. analyzed and interpreted the data, J.A.B., M.J.P., S.K.L. and M.L.C. wrote the manuscript. J.Y.C. and M.L.C. supervised the study. All authors read and approved the final manuscript.

\section{Funding}

This research was supported by Basic Science Research Program through the National Research Foundation of Korea (NRF) funded by the Ministry of Education (grant number 2020R111A1A01072525, No. 2020R1F1A1075816) and a grant of the Korea Health Technology R\&D Project through the Korea Health Industry Development Institute (KHIDI), funded by the Ministry of Health \& Welfare, Republic of Korea (grant number HI15C3062).

\section{Availability of data and materials}

All datasets generated for this study are included in the article.

\section{Ethics approval and consent to participate}

Mice experimental procedures were approved by the Department of Laboratory Animals, Institutional Animal Care and Use Committee (IACUC) of the School of Medicine, Catholic University of Korea and conformed with all National Institutes of Health (USA) guidelines (Approval number : CUMC-2020-017701).

Informed consent was obtained from all patients, and the experimental protocol was approved by the Institutional Review Board of the Catholic University of Korea (KC19OESI0617).

\section{Consent for publication}

Informed consent was obtained from all patients. 


\section{Competing Interest}

The authors of this manuscript have no conflicts of interest.

\section{Author details}

${ }^{1}$ The Rheumatism Research Center, Catholic Research Institute of Medical Science, College of Medicine, The Catholic University of Korea, 222, Banpo-daero, Seocho-gu, Seoul, 06591, Republic of Korea

${ }^{2}$ Department of Biomedicine \& Health Sciences, College of Medicine, The Catholic University of Korea, 222, Banpo-daero, Seocho-gu, Seoul, 06591, Republic of Korea ${ }^{3}$ Department of Medical Lifescience, College of Medicine, The Catholic University of Korea, 222, Banpo-daero, Seocho-gu, Seoul, 06591, Republic of Korea ${ }^{4}$ Division of Hepatology, Department of Internal Medicine, Seoul St. Mary's Hospital, College of Medicine, The Catholic University of Korea, 222, Banpo-daero, Seocho-gu, Seoul, 06591, Republic of Korea

\section{References}

1. Dumont FJ: FK506, an immunosuppressant targeting calcineurin function. Curr Med Chem 2000, 7:731-748.

2. Ferrara JLM, Levine JE, Reddy P, Holler E: Graft-versus-host disease. Lancet 2009, 373:1550-1561.

3. Hart A, Smith JM, Skeans MA, Gustafson SK, Stewart DE, Cherikh WS, Wainright JL, Kucheryavaya A, Woodbury M, Snyder JJ, et al: OPTN/SRTR 2015 Annual Data Report: Kidney. Am J Transplant 2017, 17 Suppl 1:21-116.

4. Clipstone NA, Crabtree GR: Identification of calcineurin as a key signalling enzyme in T-lymphocyte activation. Nature 1992, 357:695-697.

5. Barshes NR, Goodpastor SE, Goss JA: Pharmacologic immunosuppression. Front Biosci 2004, 9:411-420.

6. Cook LG, Chiasson VL, Long C, Wu GY, Mitchell BM: Tacrolimus reduces nitric oxide synthase function by binding to FKBP rather than by its calcineurin effect. Kidney Int 2009, 75:719-726.

7. Jenq RR, van den Brink MR: Allogeneic haematopoietic stem cell transplantation: individualized stem cell and immune therapy of cancer. Nat Rev Cancer 2010, 10:213-221.

8. Henrik Ekberg MD, Ph.D., Helio Tedesco-Silva, M.D., Alper Demirbas, M.D., Štefan Vítko, M.D., Björn Nashan, M.D., Ph.D., Alp Gürkan, M.D., F.A.C.S., Raimund Margreiter, M.D., Christian Hugo, M.D., Josep M. Grinyó, M.D., Ulrich Frei, M.D., Yves Vanrenterghem, M.D., Ph.D., Pierre Daloze, M.D., et al.: Reduced Exposure to Calcineurin Inhibitors in Renal Transplantation. N Engl J Med 2007, 357:2562-2575.

9. Jacquet A, Francois H, Frangie C, Ahmad L, Charpentier B, Durrbach A: Prevention of calcineurin inhibitor nephrotoxicity in renal transplantation. Transp/ Immunol 2008, 20:29-31.

10. Tourret J, Willing BP, Dion S, MacPherson J, Denamur E, Finlay BB: Immunosuppressive Treatment Alters Secretion of Ileal Antimicrobial Peptides and Gut Microbiota, and Favors Subsequent 
Colonization by Uropathogenic Escherichia coli. Transplantation 2017, 101:74-82.

11. Jenq RR, Ubeda C, Taur Y, Menezes CC, Khanin R, Dudakov JA, Liu C, West ML, Singer NV, Equinda $\mathrm{MJ}$, et al: Regulation of intestinal inflammation by microbiota following allogeneic bone marrow transplantation. J Exp Med 2012, 209:903-911.

12. Taur Y, Jenq RR, Perales MA, Littmann ER, Morjaria S, Ling L, No D, Gobourne A, Viale A, Dahi PB, et al: The effects of intestinal tract bacterial diversity on mortality following allogeneic hematopoietic stem cell transplantation. Blood 2014, 124:1174-1182.

13. Shono Y, Docampo MD, Peled JU, Perobelli SM, Jenq RR: Intestinal microbiota-related effects on graft-versus-host disease. Int J Hematol 2015, 101:428-437.

14. Atarashi K, Tanoue T, Shima T, Imaoka A, Kuwahara T, Momose Y, Cheng G, Yamasaki S, Saito T, Ohba Y, et al: Induction of colonic regulatory T cells by indigenous Clostridium species. Science 2011, 331:337-341.

15. Atarashi K, Tanoue T, Oshima K, Suda W, Nagano Y, Nishikawa H, Fukuda S, Saito T, Narushima S, Hase $\mathrm{K}$, et al: Treg induction by a rationally selected mixture of Clostridia strains from the human microbiota. Nature 2013, 500:232-236.

16. Narushima S, Sugiura Y, Oshima K, Atarashi K, Hattori M, Suematsu M, Honda K: Characterization of the 17 strains of regulatory T cell-inducing human-derived Clostridia. Gut Microbes 2014, 5:333-339.

17. Jenq RR, Taur Y, Devlin SM, Ponce DM, Goldberg JD, Ahr KF, Littmann ER, Ling L, Gobourne AC, Miller LC, et al: Intestinal Blautia Is Associated with Reduced Death from Graft-versus-Host Disease. Biol Blood Marrow Transplant 2015, 21:1373-1383.

18. Staffas A, Burgos da Silva M, van den Brink MR: The intestinal microbiota in allogeneic hematopoietic cell transplant and graft-versus-host disease. Blood 2017, 129:927-933.

19. Vieira AT, Teixeira MM, Martins FS: The role of probiotics and prebiotics in inducing gut immunity. Front Immunol 2013, 4:445.

20. Gerbitz A, Schultz M, Wilke A, Linde HJ, Scholmerich J, Andreesen R, Holler E: Probiotic effects on experimental graft-versus-host disease: let them eat yogurt. Blood 2004, 103:4365-4367.

21. Jones SE, Versalovic J: Probiotic Lactobacillus reuteri biofilms produce antimicrobial and antiinflammatory factors. BMC Microbiol 2009, 9:35.

22. Holler E, Butzhammer P, Schmid K, Hundsrucker C, Koestler J, Peter K, Zhu W, Sporrer D, Hehlgans T, Kreutz $\mathrm{M}$, et al: Metagenomic analysis of the stool microbiome in patients receiving allogeneic stem cell transplantation: loss of diversity is associated with use of systemic antibiotics and more pronounced in gastrointestinal graft-versus-host disease. Biol Blood Marrow Transplant 2014, 20:640-645.

23. Fukui J, Inaba M, Ueda Y, Miyake T, Hosaka N, Kwon AH, Sakaguchi Y, Tsuda M, Omae M, Kamiyama $\mathrm{Y}$, Ikehara S: Prevention of graft-versus-host disease by intra-bone marrow injection of donor T cells. Stem Cells 2007, 25:1595-1601.

24. Kim SY, Park MJ, Kwon JE, Jung KA, Jhun JY, Lee SY, Seo HB, Ryu JY, Beak JA, Choi JY, Cho ML: Cucurbitacin E ameliorates acute graft-versus-host disease by modulating Th17 cell subsets and 
inhibiting STAT3 activation. Immunol Lett 2018, 203:62-69.

25. Steinmann B, Superti-Furga A, Bruckner P: Mechanism of action of FK $\mathbf{5 0 6}$ and cyclosporin. Lancet 1991, 337:439.

26. Kondo H, Abe T, Hashimoto H, Uchida S, Irimajiri S, Hara M, Sugawara S: Efficacy and safety of tacrolimus (FK506) in treatment of rheumatoid arthritis: a randomized, double blind, placebo controlled dose-finding study. J Rheumatol 2004, 31:243-251.

27. Yocum DE, Furst DE, Bensen WG, Burch FX, Borton MA, Mengle-Gaw LJ, Schwartz BD, Wisememandle W, Mekki QA, Tacrolimus RASG: Safety of tacrolimus in patients with rheumatoid arthritis: long-term experience. Rheumatology (Oxford) 2004, 43:992-999.

28. Jacques F, Gaboury I, Christie S, Grand'maison F: Combination therapy of interferon Beta-1b and tacrolimus: a pilot safety study. Mult Scler Int 2012, 2012:935921.

29. Devaux CA, Million M, Raoult D: The Butyrogenic and Lactic Bacteria of the Gut Microbiota Determine the Outcome of Allogenic Hematopoietic Cell Transplant. Front Microbiol 2020, 11:1642.

30. Staatz CE, Tett SE: Clinical pharmacokinetics and pharmacodynamics of tacrolimus in solid organ transplantation. Clin Pharmacokinet 2004, 43:623-653.

31. Shuker N, van Gelder T, Hesselink DA: Intra-patient variability in tacrolimus exposure: causes, consequences for clinical management. Transplant Rev (Orlando) 2015, 29:78-84.

32. Jiang JW, Ren ZG, Lu HF, Zhang H, Li A, Cui GY, Jia JJ, Xie HY, Chen XH, He Y, et al: Optimal immunosuppressor induces stable gut microbiota after liver transplantation. World $\mathrm{J}$ Gastroenterol 2018, 24:3871-3883.

33. Bermudez-Brito M, Plaza-Diaz J, Munoz-Quezada S, Gomez-Llorente C, Gil A: Probiotic mechanisms of action. Ann Nutr Metab 2012, 61:160-174.

34. Kwon HK, Lee CG, So JS, Chae CS, Hwang JS, Sahoo A, Nam JH, Rhee JH, Hwang KC, Im SH: Generation of regulatory dendritic cells and CD4+Foxp3+ T cells by probiotics administration suppresses immune disorders. Proc Natl Acad Sci U S A 2010, 107:2159-2164.

35. Park JS, Choi JW, Jhun J, Kwon JY, Lee BI, Yang CW, Park SH, Cho ML: Lactobacillus acidophilus Improves Intestinal Inflammation in an Acute Colitis Mouse Model by Regulation of Th17 and Treg Cell Balance and Fibrosis Development. J Med Food 2018, 21:215-224.

36. Britton RA, Irwin R, Quach D, Schaefer L, Zhang J, Lee T, Parameswaran N, McCabe LR: Probiotic L. reuteri treatment prevents bone loss in a menopausal ovariectomized mouse model. $J$ Cell Physiol 2014, 229:1822-1830.

37. Ren ZG, Liu H, Jiang JW, Jiang L, Chen H, Xie HY, Zhou L, Zheng SS: Protective effect of probiotics on intestinal barrier function in malnourished rats after liver transplantation. Hepatobiliary Pancreat Dis Int 2011, 10:489-496.

38. Lu Y, Sakamaki S, Kuroda H, Kusakabe T, Konuma Y, Akiyama T, Fujimi A, Takemoto N, Nishiie K, Matsunaga T, et al: Prevention of lethal acute graft-versus-host disease in mice by oral administration of T helper 1 inhibitor, TAK-603. Blood 2001, 97:1123-1130. 
39. Reddy P: Pathophysiology of acute graft-versus-host disease. Hemato/ Onco/ 2003, 21:149-161.

40. Carlson MJ, West ML, Coghill JM, Panoskaltsis-Mortari A, Blazar BR, Serody JS: In vitro-differentiated TH17 cells mediate lethal acute graft-versus-host disease with severe cutaneous and pulmonary pathologic manifestations. Blood 2009, 113:1365-1374.

41. Kappel LW, Goldberg GL, King CG, Suh DY, Smith OM, Ligh C, Holland AM, Grubin J, Mark NM, Liu C, et al: IL-17 contributes to CD4-mediated graft-versus-host disease. Blood 2009, 113:945-952.

42. Zhao XY, Xu LL, Lu SY, Huang XJ: IL-17-producing T cells contribute to acute graft-versus-host disease in patients undergoing unmanipulated blood and marrow transplantation. Eur J Immunol 2011, 41:514-526.

43. Gutierrez-Hoya A, Lopez-Santiago R, Vela-Ojeda J, Montiel-Cervantes L, Rodriguez-Cortes O, RosalesGarcia V, Paredes-Cervantes V, Flores-Mejia R, Sandoval-Borrego D, Moreno-Lafont M: Role of CD8 Regulatory T Cells versus Tc1 and Tc17 Cells in the Development of Human Graft-versus-Host Disease. J Immunol Res 2017, 2017:1236219.

44. Lu SY, Liu KY, Liu DH, Xu LP, Huang XJ: High frequencies of CD62L(+) naive regulatory T cells in allografts are associated with a low risk of acute graft-versus-host disease following unmanipulated allogeneic haematopoietic stem cell transplantation. Clin Exp Immunol 2011, 165:264-277.

45. Mclver Z, Melenhorst JJ, Wu C, Grim A, Ito S, Cho I, Hensel N, Battiwalla M, Barrett AJ: Donor lymphocyte count and thymic activity predict lymphocyte recovery and outcomes after matchedsibling hematopoietic stem cell transplant. Haematologica 2013, 98:346-352.

46. Noguchi $S$, Hattori M, Sugiyama $H$, Hanaoka A, Okada S, Yoshida T: Lactobacillus plantarum NRIC1832 enhances IL-10 production from CD4(+) T cells in vitro. Biosci Biotechnol Biochem 2012, 76:1925-1931.

47. Jo SG, Noh EJ, Lee JY, Kim G, Choi JH, Lee ME, Song JH, Chang JY, Park JH: Lactobacillus curvatus WiKim38 isolated from kimchi induces IL-10 production in dendritic cells and alleviates DSS-induced colitis in mice. J Microbiol 2016, 54:503-509.

48. Wu X, He B, Liu J, Feng H, Ma Y, Li D, Guo B, Liang C, Dang L, Wang L, et al: Molecular Insight into Gut Microbiota and Rheumatoid Arthritis. Int J Mol Sci 2016, 17:431.

49. Lee N, Kim WU: Microbiota in T-cell homeostasis and inflammatory diseases. Exp Mol Med 2017, 49:e340.

50. Campos-Mora M, Contreras-Kallens P, Galvez-Jiron F, Rojas M, Rojas C, Refisch A, Cerda O, PinoLagos K: CD4+Foxp3+T Regulatory Cells Promote Transplantation Tolerance by Modulating Effector CD4+ T Cells in a Neuropilin-1-Dependent Manner. Front Immunol 2019, 10:882.

51. Dall'Era M, Pauli ML, Remedios K, Taravati K, Sandova PM, Putnam AL, Lares A, Haemel A, Tang Q, Hellerstein M, et al: Adoptive Treg Cell Therapy in a Patient With Systemic Lupus Erythematosus. Arthritis Rheumatol 2019, 71:431-440.

52. Park MJ, Baek JA, Kim SY, Jung KA, Choi JW, Park SH, Kwok SK, Cho ML: Myeloid-derived suppressor cells therapy enhance immunoregulatory properties in acute graft versus host disease with combination of regulatory T cells. J Transl Med 2020, 18:483. 
53. Li S, Wang H, Wu H, Chang X: Therapeutic Effect of Exogenous Regulatory T Cells on Collageninduced Arthritis and Rheumatoid Arthritis. Cell Transplant 2020, 29:963689720954134.

54. Eltzschig HK, Ibla JC, Furuta GT, Leonard MO, Jacobson KA, Enjyoji K, Robson SC, Colgan SP: Coordinated adenine nucleotide phosphohydrolysis and nucleoside signaling in posthypoxic endothelium: role of ectonucleotidases and adenosine A2B receptors. J Exp Med 2003, 198:783796.

55. Kordass T, Osen W, Eichmuller SB: Controlling the Immune Suppressor: Transcription Factors and MicroRNAs Regulating CD73/NT5E. Front Immunol 2018, 9:813.

56. Hill JA, Feuerer M, Tash K, Haxhinasto S, Perez J, Melamed R, Mathis D, Benoist C: Foxp3 transcription-factor-dependent and -independent regulation of the regulatory $\mathrm{T}$ cell transcriptional signature. Immunity 2007, 27:786-800.

57. Overacre-Delgoffe AE, Chikina M, Dadey RE, Yano H, Brunazzi EA, Shayan G, Horne W, Moskovitz JM, Kolls JK, Sander C, et al: Interferon-gamma Drives Treg Fragility to Promote Anti-tumor Immunity. Cell 2017, 169:1130-1141 e1111.

58. Sidaway P: Immunotherapy: Neuropilin-1 is required for Treg stability. Nat Rev Clin Oncol2017, 14:458.

59. Worthington JJ, Kelly A, Smedley C, Bauche D, Campbell S, Marie JC, Travis MA: Integrin alphavbeta8-Mediated TGF-beta Activation by Effector Regulatory T Cells Is Essential for Suppression of T-Cell-Mediated Inflammation. Immunity 2015, 42:903-915.

60. Sebastian M, Lopez-Ocasio M, Metidji A, Rieder SA, Shevach EM, Thornton AM: Helios Controls a Limited Subset of Regulatory T Cell Functions. J Immuno/ 2016, 196:144-155.

61. Li AL, Meng XC, Duan CC, Huo GC, Zheng QL, Li D: Suppressive effects of oral administration of heatkilled Lactobacillus acidophilus on T helper-17 immune responses in a bovine beta-lactoglobulinsensitized mice model. Biol Pharm Bull 2013, 36:202-207.

62. Dar HY, Shukla P, Mishra PK, Anupam R, Mondal RK, Tomar GB, Sharma V, Srivastava RK: Lactobacillus acidophilus inhibits bone loss and increases bone heterogeneity in osteoporotic mice via modulating Treg-Th17 cell balance. Bone Rep 2018, 8:46-56.

\section{Figures}


a
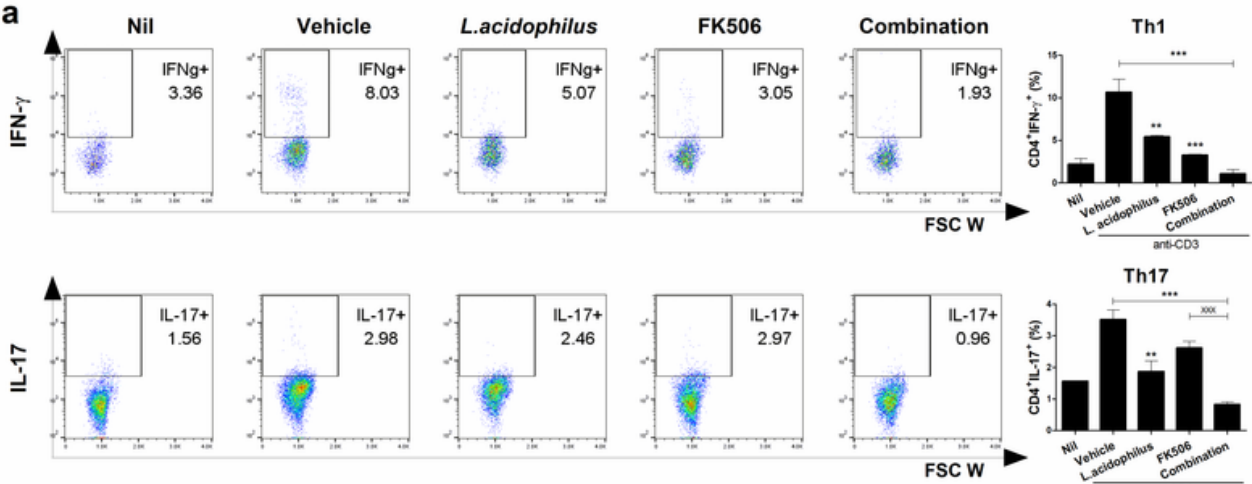

Th17
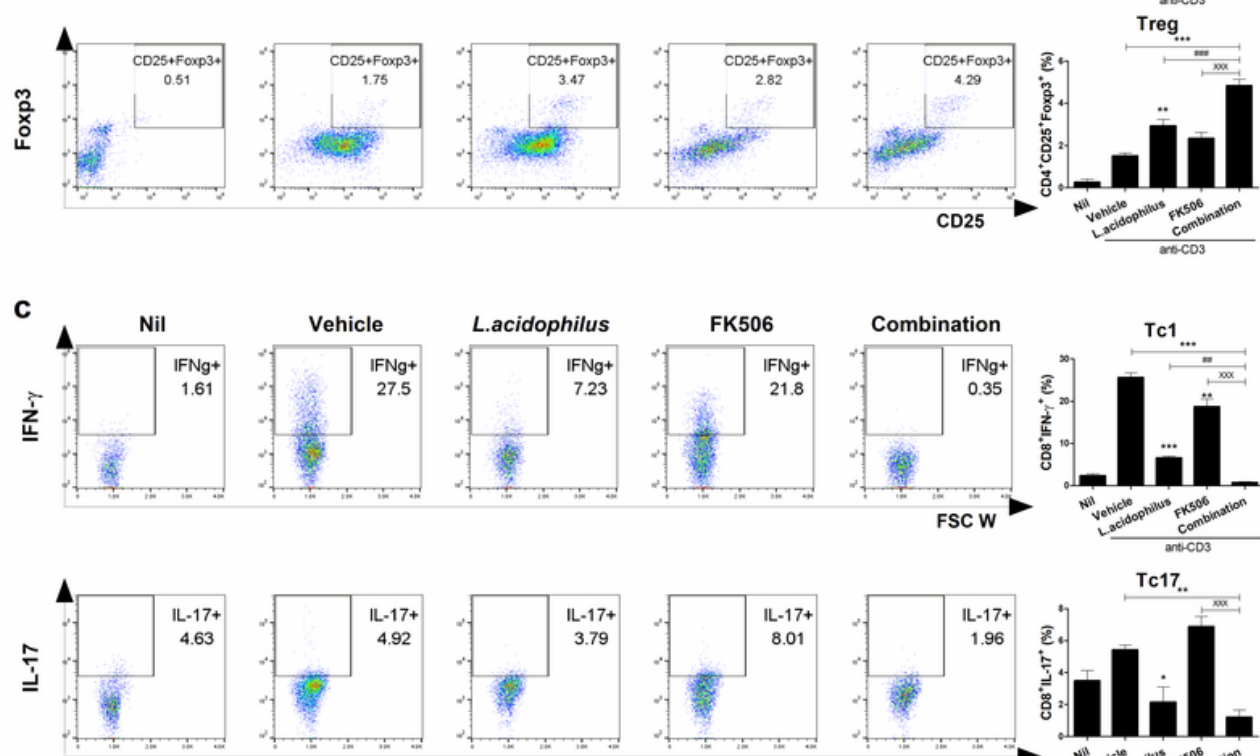

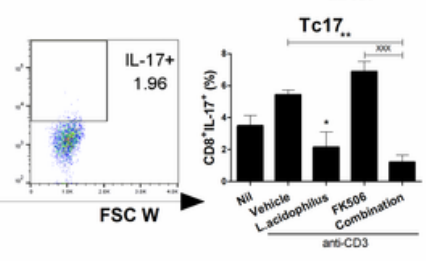

b
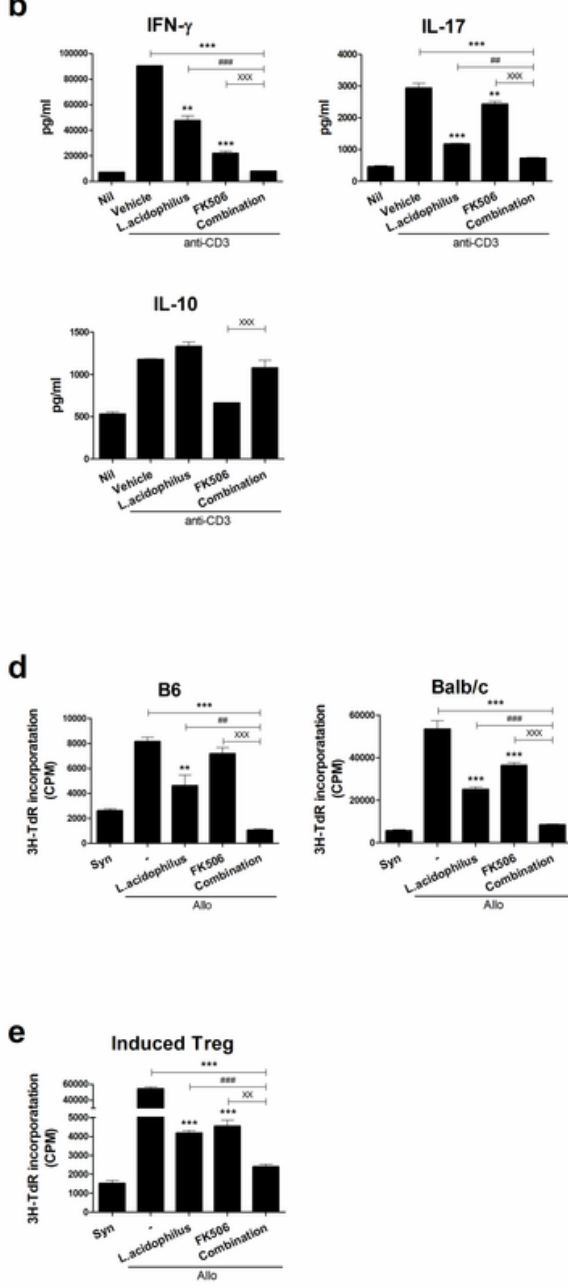

Figure 1

Combination treatment modulates mouse T cell subtype proliferation in vitro. a Proportions of Th1, Th17, and Treg cells after combination treatment. Splenocytes from normal B6 mice were stimulated with antiCD3 in the presence of L. acidophilus and/or FK506 for 3 days and analyzed by flow cytometry. b IFN-y, IL-17, and IL-10 concentrations in culture supernatants as determined by ELISA. c Proportions of Tc1 and Tc17 cells after combination treatment analyzed by flow cytometry. $d$ In the mixed lymphocyte reaction assay, 2 × 105 B/c (B6) splenic CD4+-T cells (responders) were incubated with 2 x 105 irradiated B/c (B6) (syngeneic stimulators [Syn]) or B6 (B/C) (allogeneic stimulators [Allo]) splenic APCs for 4 days. T-cell proliferation was measured by $3[\mathrm{H}]-\mathrm{TdR}$ incorporation. e In vitro co-culture systems, responder cells $(2 \times$ $105)$ and irradiated APCs $(2 \times 105)$ were co-cultured with sorted L. acidophilus and/or FK506-induced Treg $(1 \times 103$; each induced Treg to responder cells ratio was 1:40) for 4 days. T-cell proliferation was measured by $3[\mathrm{H}]-\mathrm{TdR}$ incorporation. Data are means \pm SEM of three independent experiments. ( ${ }^{*}$, each sample versus vehicle; \#, combination versus $L$. acidophilus; $X$, combination versus $F K 506, *$, \#, $X p<0.05$, $\star \star$, \#\#, XXp < 0.01, ***, \#\#\#, XXXp < 0.005). 
a

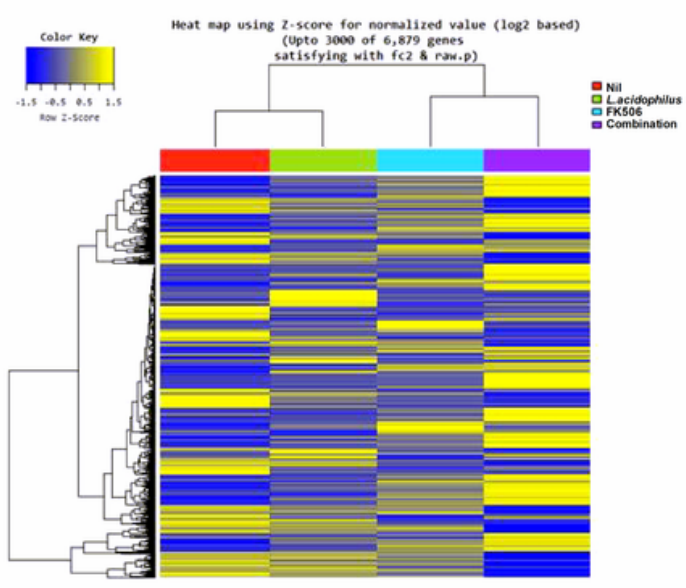

b

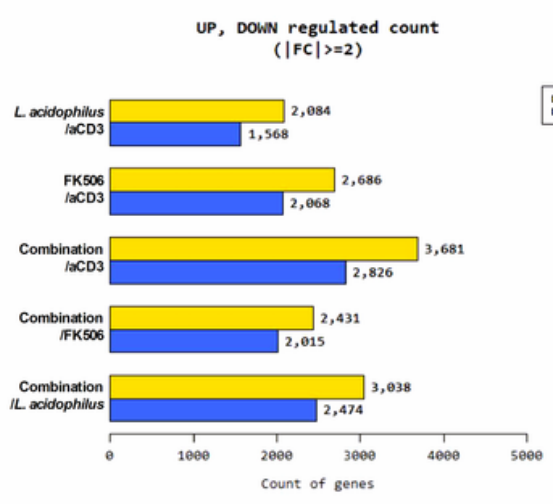

C

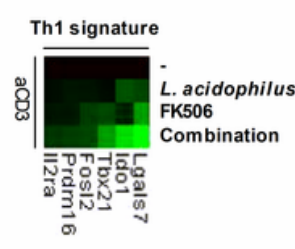

Th1
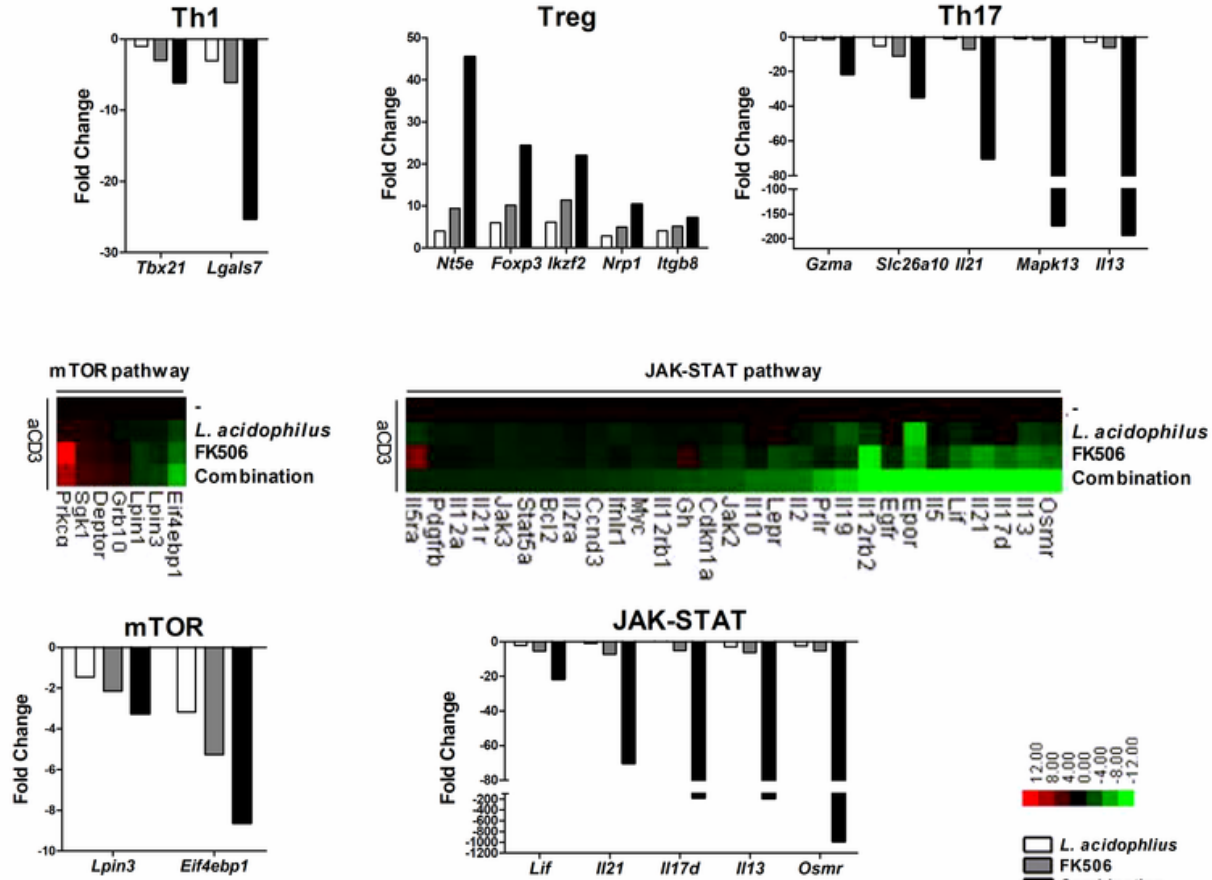
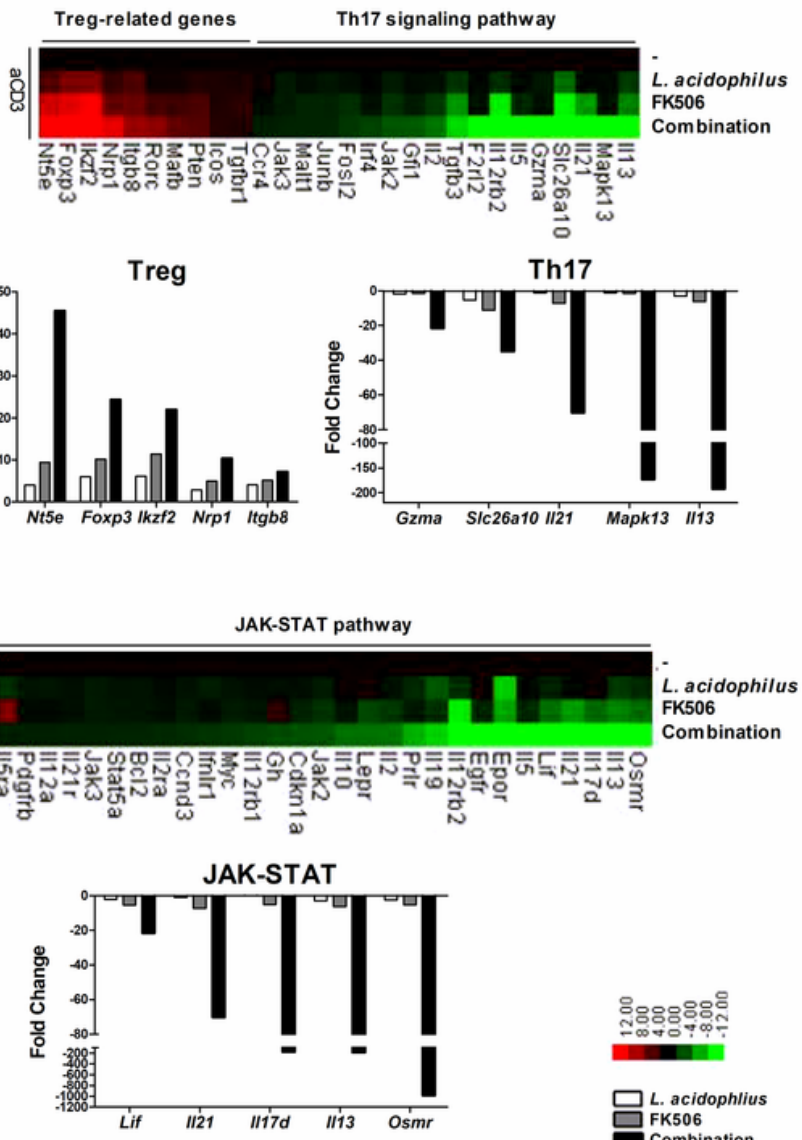

ㅇํㅇ용ํำ ำเดฺฺ

员. acidophlius Combination

\section{Figure 2}

Gene expression profiling by RNA-seq among CD4+-T cells treated with L. acidophilus, FK506, and combination. a Hierarchical cluster heatmap of mouse anti-CD3 stimulated CD4+-T cells treated with L. acidophilus and/or FK506. b Significantly differentially expressed genes and c significant differences in Th1, Th17, and Treg populations and mTOR and JAK-STAT pathway activities versus only anti-CD3treated CD4+-T cells. 
a
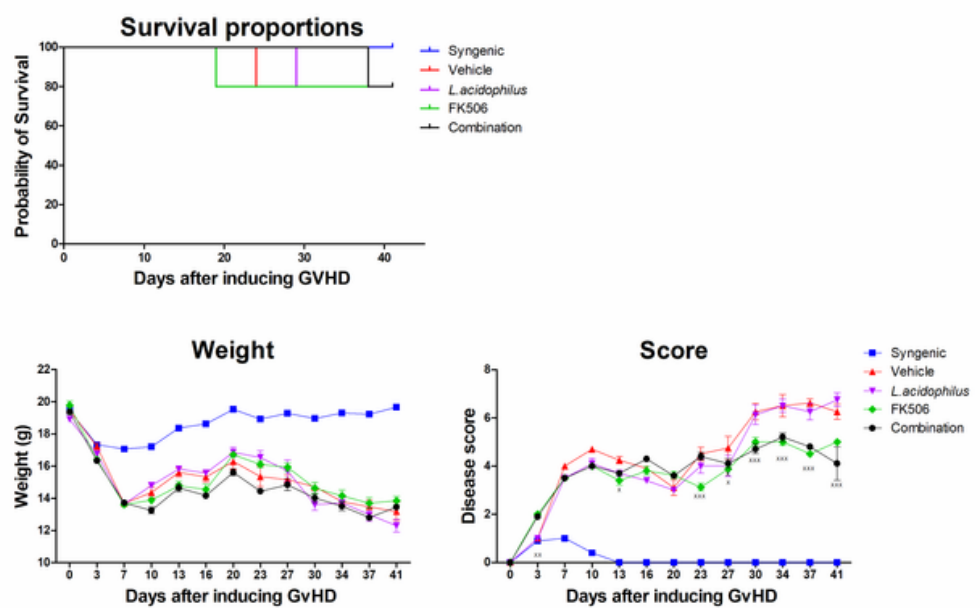

b
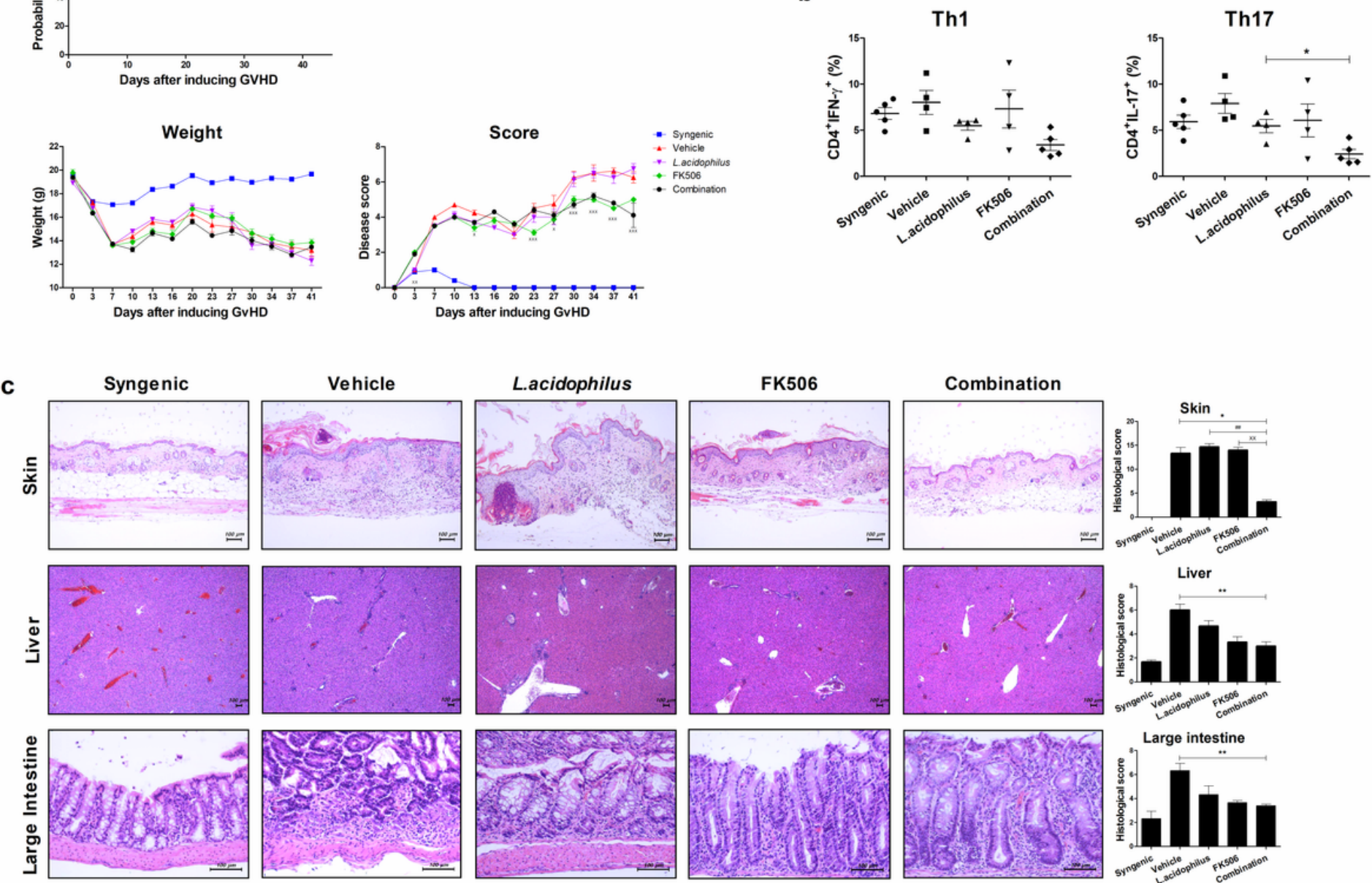

Figure 3

Combination treatment reduced the severity of GvHD. a Survival rate, weight loss, and clinical score after BMT in GvHD mice. Allogeneic-transplanted animals showed a significantly increased GvHD score compared with syngeneic-transplanted animals. The clinical GvHD score was the sum of weight loss, posture, activity, fur, and skin on a scale of 0 to 2 ( $n=5$ per group and repeated 3 times). b Four weeks after BMT, IFN- $\gamma$ and IL-17 expression in mouse CD4+-T cells as analyzed by flow cytometry. C Histopathology of the skin, liver, and large intestine after BMT ( $n=5$ per group) from one of two independent experiments. Sections were stained with hematoxylin and eosin (original magnification; liver $\times 40$, skin and large intestine $\times 200$; scale bar, $100 \mu \mathrm{m}$ ). Histopathology score of skin, liver, and large intestine tissues. Results are means \pm SEM (*, each sample versus vehicle; \#, combination versus $L$.

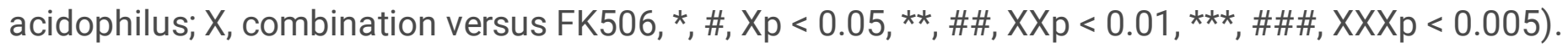


a
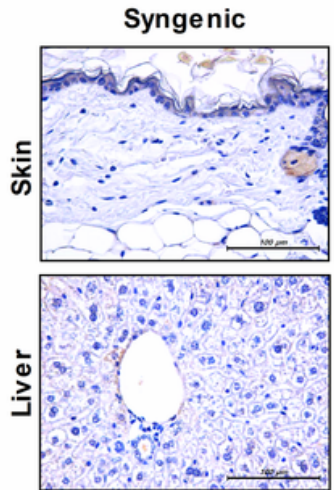

b
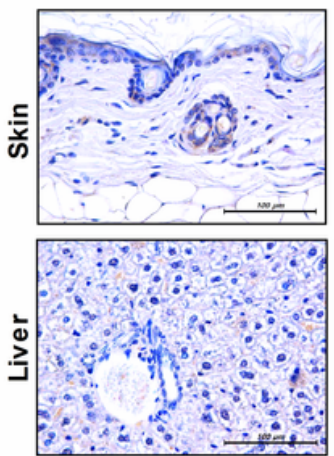

C
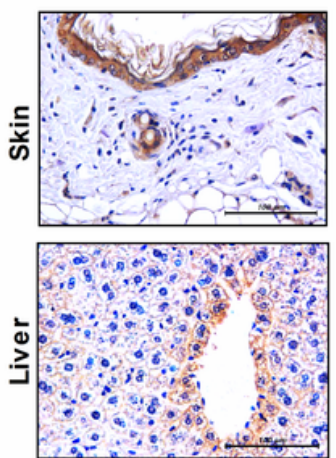

Vehicle
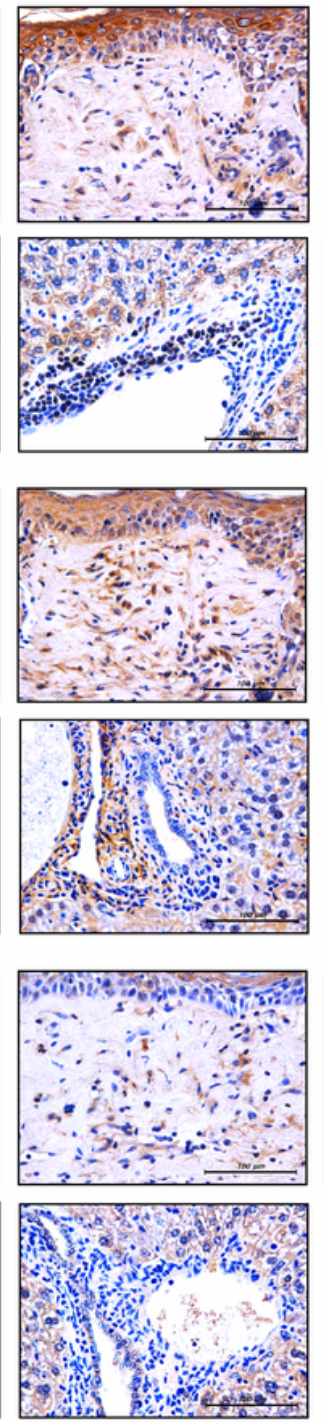

L.acidophilus
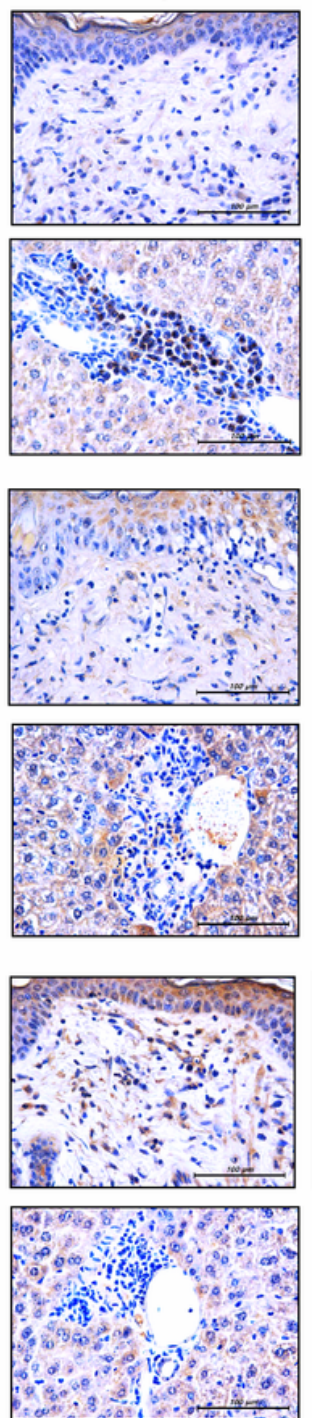

FK506
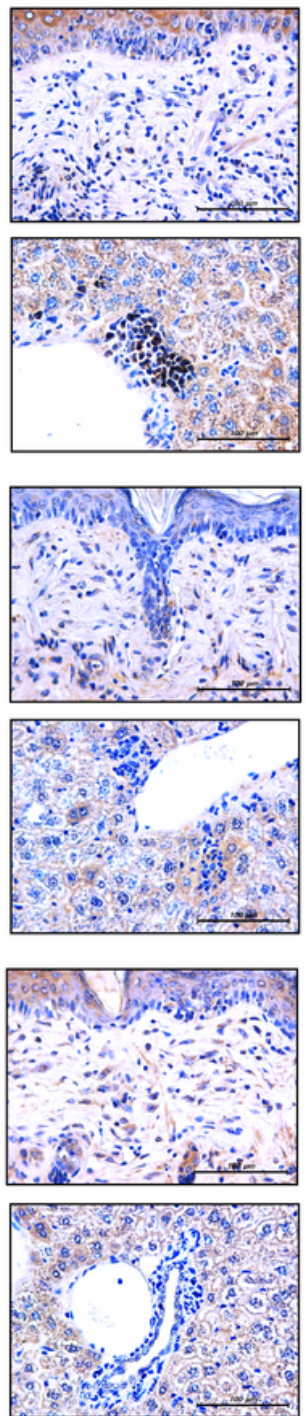

Combination
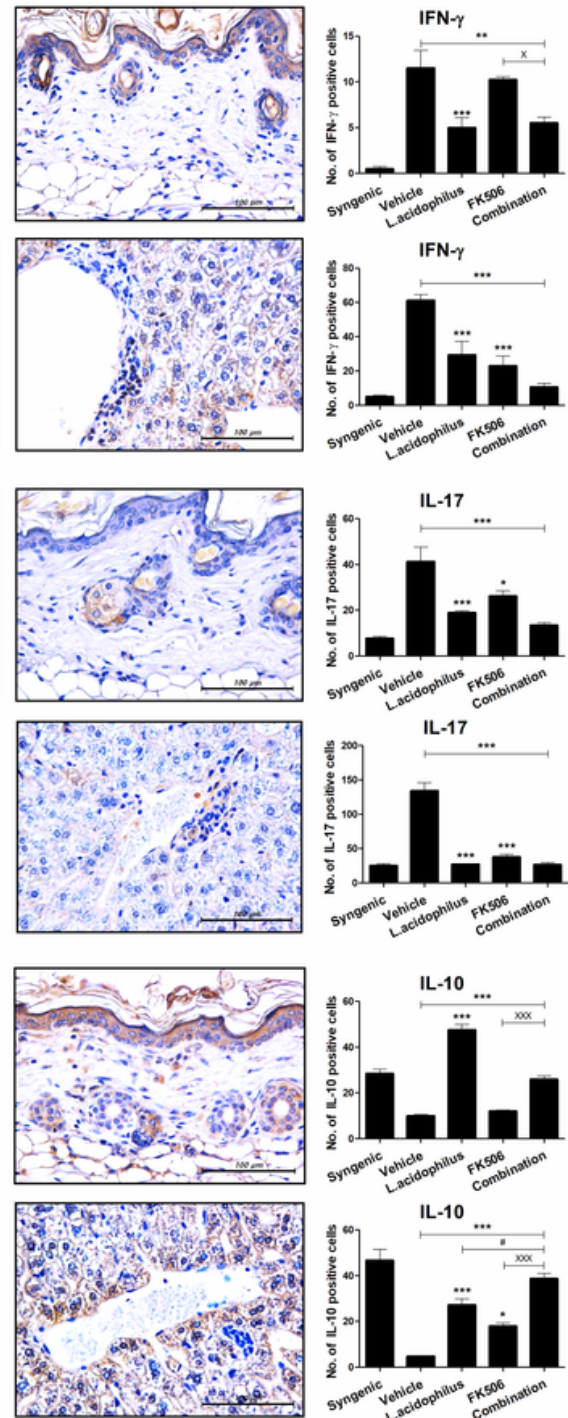

\section{Figure 4}

Combination treatment reduces and increases, respectively, the secretion of pro- and anti-inflammatory cytokines. Immunohistochemical images of tissues stained with a anti-IFN- $\gamma, \mathrm{b}$ anti-IL-17, and $\mathrm{c}$ anti-IL-10 antibodies (original magnification $\times 400$, scale bars, $100 \mu \mathrm{m}$ ). 
a
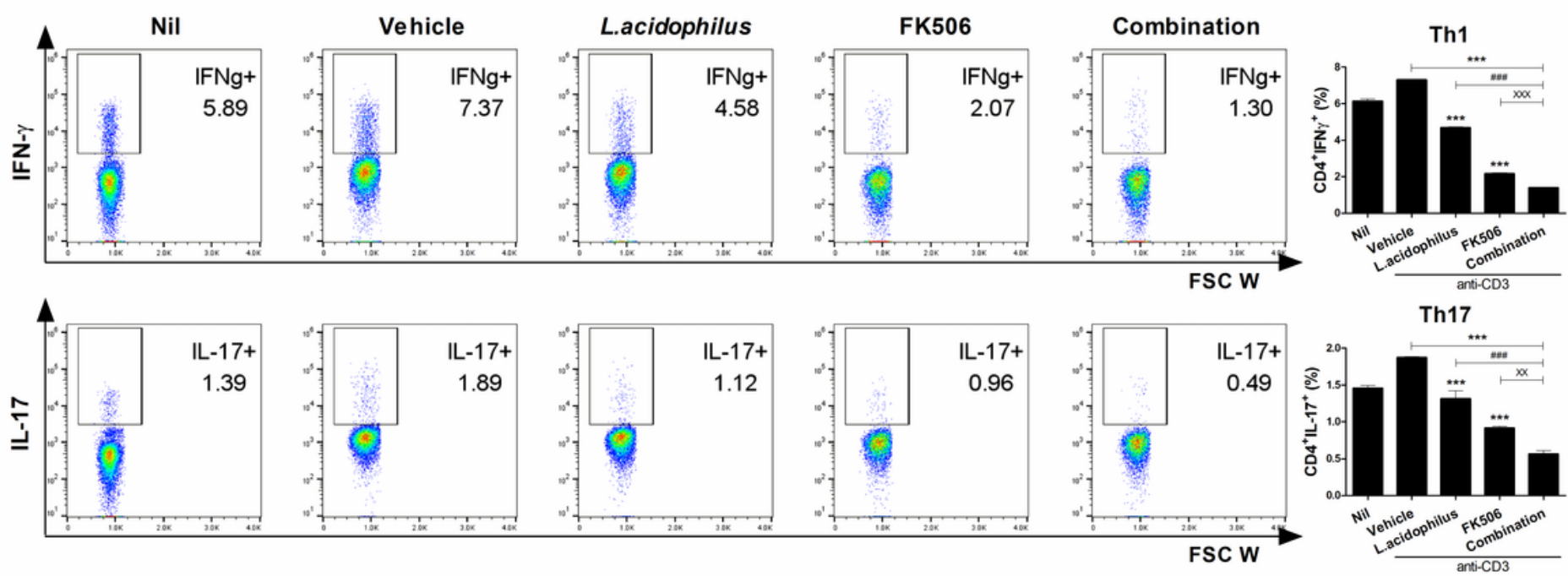

b
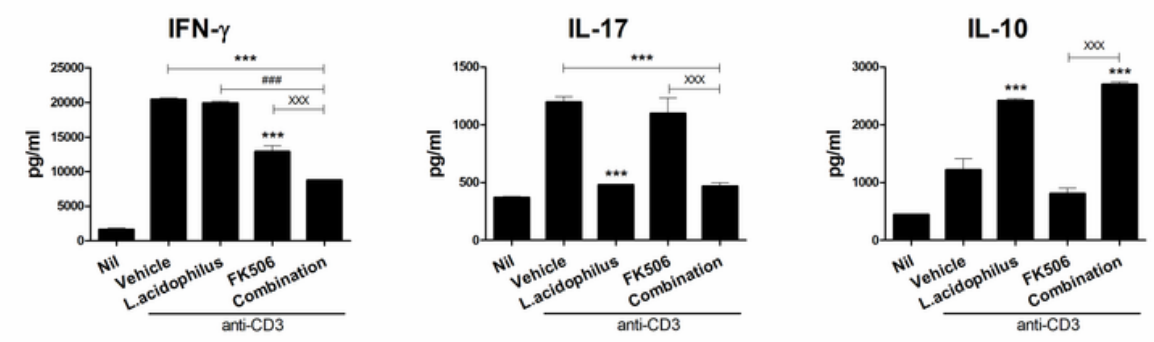

C

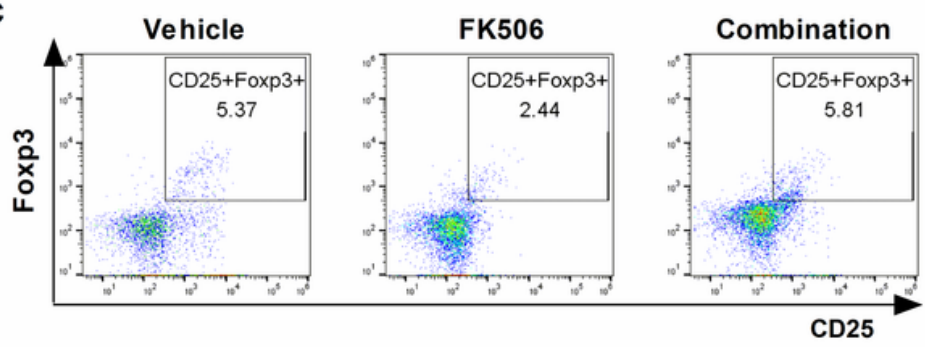

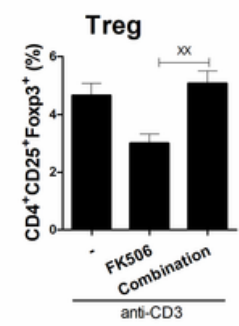

d

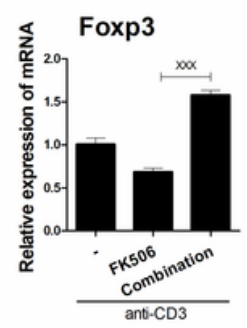

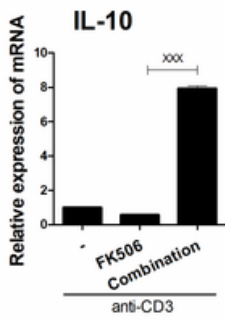

Figure 5

Effect of the combination treatment on healthy PBMCs in vitro. a Proportions of Th1 and Th17 cells. Human PBMCs from healthy donors were stimulated with anti-CD3 in the presence of L. acidophilus and/or FK506 for 3 days and analyzed by flow cytometry. b IFN- $y$, IL-17, and IL-10 concentrations in culture supernatants as determined by ELISA. c After stimulation of healthy PBMCs with anti-CD3 for 3 days, proportion of Treg cells were determined by flow cytometry and d Foxp3 and IL-10 mRNA levels were determined by real-time PCR ( ${ }^{*}$, each sample versus vehicle; \#, combination versus L. acidophilus; $X$, combination versus FK506, *, \#, Xp <0.05, **, \#\#, XXp < 0.01, ***, \#\#\#, XXXp <0.005). 
a
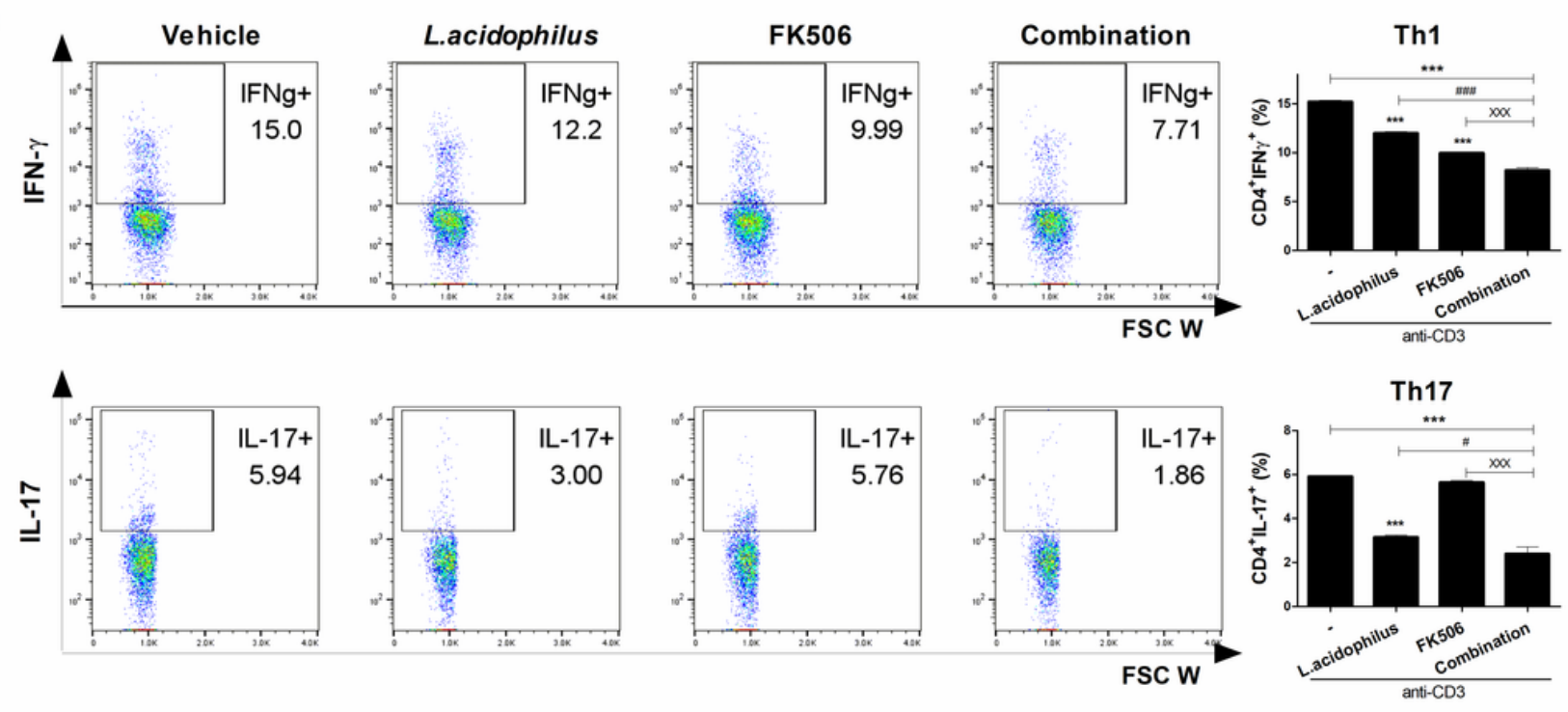

b
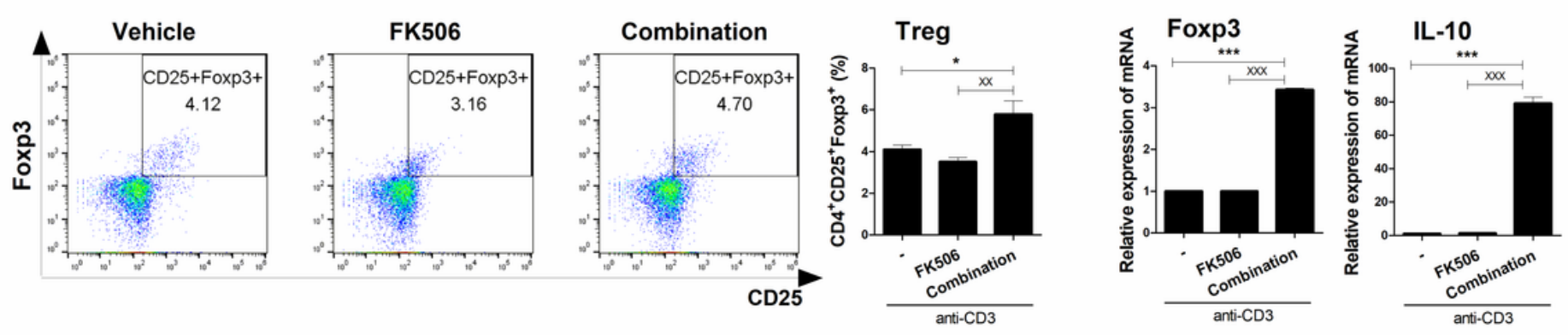

\section{Figure 6}

Effect of the combination treatment on LT-patient PBMCs in vitro. a Proportions Th1 and Th17 cells among PBMCs treated with L. acidophilus and/or FK506. Patient PBMCs were stimulated with anti-CD3 in the presence of L. acidophilus and/or FK506 for 3 days and analyzed by flow cytometry. b Proportion Treg cells were analysis by flow cytometry, and Foxp3 and IL-10 mRNA levels were determined by realtime PCR after stimulation of LT-patient PBMCs with anti-CD3 for 3 days. Data are means \pm SEM of three independent experiments ( ${ }^{*}$, each sample versus vehicle; \#, combination versus $L$. acidophilus; $X$, combination versus FK506, *, \#, Xp <0.05, **, \#\#, XXp < 0.01, ***, \#\#\#, XXXp <0.005). 